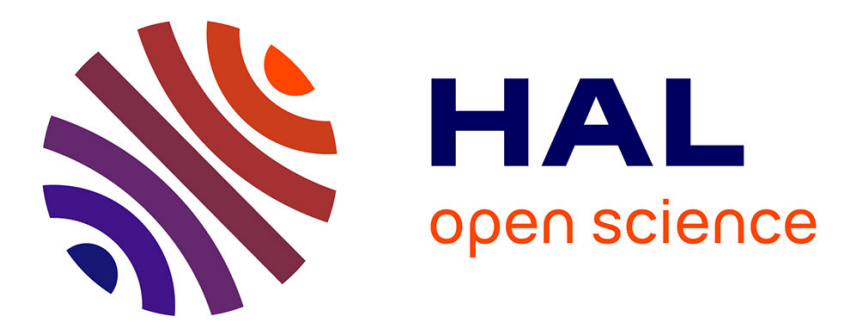

\title{
Climate change impacts in European forests: the expert views of local observers
}

Peter Spathelf, Ernst van Der Maaten, Marieke van Der Maaten-Theunissen, Matteo Campioli, Dorota Dobrowolska

\section{- To cite this version:}

Peter Spathelf, Ernst van Der Maaten, Marieke van Der Maaten-Theunissen, Matteo Campioli, Dorota Dobrowolska. Climate change impacts in European forests: the expert views of local observers. Annals of Forest Science, 2014, 71 (2), pp.131-137. 10.1007/s13595-013-0280-1 . hal-01098395

\section{HAL Id: hal-01098395 \\ https://hal.science/hal-01098395}

Submitted on 24 Dec 2014

HAL is a multi-disciplinary open access archive for the deposit and dissemination of scientific research documents, whether they are published or not. The documents may come from teaching and research institutions in France or abroad, or from public or private research centers.
L'archive ouverte pluridisciplinaire HAL, est destinée au dépôt et à la diffusion de documents scientifiques de niveau recherche, publiés ou non, émanant des établissements d'enseignement et de recherche français ou étrangers, des laboratoires publics ou privés. 


\title{
Climate change impacts in European forests: the expert views of local observers
}

\author{
Peter Spathelf • Ernst van der Maaten • \\ Marieke van der Maaten-Theunissen . \\ Matteo Campioli • Dorota Dobrowolska
}

Received: 25 January 2013 / Accepted: 24 February 2013/Published online: 5 April 2013

(C) INRA and Springer-Verlag France 2013

Keywords Impact assessment · Vulnerability · Adaptation · Regional differences $\cdot$ Forest management

\section{Introduction}

Forests respond differently to changes in climate depending on individual site characteristics and tree status. Site conditions may buffer or boost impacts of heat, drought, and storm events. Considering contemporary changes in climate (Christensen et al. 2007), warming may increase forest productivity in those parts of Europe where growth

\section{Handling Editor: Erwin Dreyer}

Contribution of the co-authors PS and EM designed the questionnaire within working group 1 of COST Action ECHOES and coordinated the study. Data analysis and writing of the manuscript was done in cooperation with MMT, MC, and DD.

\section{P. Spathelf $(\square)$}

Faculty of Forest and Environment, Eberswalde University for sustainable development, Alfred-Möller Str. 1,

16225 Eberswalde, Germany

e-mail: peter.spathelf@hnee.de

E. van der Maaten $\cdot$ M. van der Maaten-Theunissen Institute for Forest Growth, Albert-Ludwigs-University,

Tennenbacher Str. 4 ,

79106 Freiburg, Germany

\section{Campioli}

Research Group of Plant and Vegetation Ecology, Department of Biology, University of Antwerp, Universiteitsplein 1, Wilrijk, 2610 Antwerp, Belgium

\section{Dobrowolska}

Department of Forest Ecology, Forest Research Institute, Braci leśnej 3, Sekocin Stary,

05-090 Raszyn, Poland resources like soil water are not limiting (Nabuurs et al. 2002). However, under conditions of limited resource supply and changed disturbance regime, we may expect a reduction of forest productivity and vitality (Lindner et al. 2010). Major climatic impacts on forests include both singular extreme events (changing climate variability) that are difficult to predict in time and location, as well as less obvious gradual changes (changing mean values) (Bolte et al. 2010; Reyer et al. 2013).

This study presents an analysis of the diverse aspects of climate change impacts on forests in Europe based on the expert views of local observers. Local expert knowledge provides additional (often overlooked) information on climate change impacts and fills knowledge gaps for lessdescribed European regions. Furthermore, we used expert knowledge to highlight a set of priorities for pro- and reactive forest management, taking into account differences and similarities among regions. Finally, we wanted to define "hot spots" of climate change impacts, i.e., regions, or selected tree species/stands in these regions, which are highly vulnerable and considerably exposed to negative impacts of climate change.

\section{Method}

Information underlying the analysis was collected within the COST Action FP0703 Expected Climate cHange impacts and Options for European Silviculture (ECHOES), in particular with a questionnaire. The questionnaire was distributed through the Action among a group of experts from 27 countries, working at universities, forest research institutes, and other forest authorities. These experts comprised participants to the Action and ad hoc experts contacted by the participants. 
The questionnaire comprises closed (Q5a), open (e.g., Q3b), and subjective questions (e.g., Q4 and Q5b). Especially estimations and personal opinions of the asked experts were documented, and to a lesser extent objective and quantitative indicators (see also Thies et al. 2009). When made available by the respondents, literature references were added to our analysis. The questions $(\mathrm{Q})$ read:

Q1. Which observed and expected changes in climate are of major importance in your country, considering (potential) impact(s) on forest ecosystems? Example, temperature- and precipitation-changes. Do you think that the mentioned changes in climate will become less, equally, or more important in the future?

Q2. Describe the associated (potential) impact(s) on forests! Example, impacts on productivity, phenology, vitality and mortality, migrations/shifts.

Q3. (a) Indicate the impacted tree species/provenances (ranked according to magnitude) and explain why.

(b) Describe the most severely affected site conditions, forest structures, and species compositions! Example, soil type and soil depth, water availability, topographic position, slope, aspect, open/closed canopy, un-/even-aged forest structure, pure/mixed stands.

Q4. Identify and localize on the enclosed map (Forest Map of Europe, after Päivinen et al. 2001), if possible, hot spots of climate change-induced forest vulnerability in your country.

Q5. (a) Has forest management changed at the described hot spot(s)? or (b) does forest management need to be changed? If yes, how?

The feedback to the questionnaire was good and provided expert views on climate change impacts on forests for 24 European countries representing the four bioclimatic regions (cf. Lindner et al. 2010): Boreal (Finland, Norway), Atlantic (Belgium, Czech Republic, France, Germany, Ireland, Switzerland, UK), Continental (Austria, Bulgaria, Croatia, Estonia, Hungary, Poland, Romania, Serbia, Slovakia, Slovenia), and Mediterranean (Cyprus, Greece, Italy, Portugal, Spain). The number of experts directly involved in responding the questionnaire was 62 ; the total number of experts contacted by the respondents as sources of information was not available.

\section{Results}

3.1 Observed and expected changes in climate

Answers on Q1 were generally in line with projections of the Intergovernmental Panel on Climate Change (Christensen et al. 2007). Among all mentioned observed climate change impact factors, air temperature increase and precipitation regime change were ranked first (recorded in 88 and $79 \%$ of the countries, respectively) but more frequent extreme weather events (recorded in $58 \%$ of the countries), summer drought (50\% of the countries) and wind/storm ( $29 \%$ of the countries), were also common.

\subsection{Climate change impacts on forest ecosystems}

Boreal zone Although productivity increases are expected in a future warmer climate in the Boreal zone (Zheng et al. 2002; Bergh et al. 2003), observed impacts of climate change on Boreal forests are limited up to date and no conclusive evidence of increased productivity has been found. Nevertheless, a positive growth tendency was indicated for Norway and advanced bud burst and flowering (by 3.3 to 11.0 days, respectively) were observed in Finland (Linkosalo et al. 2009). Furthermore, the projected changes in climate create an opportunity to maintain and increase biodiversity as increases in temperature may allow colonization by other species without replacing existing species on the landscape level. On the other hand, increases in temperature and changes in precipitation regime are expected to increase the risk of both invading and existing pathogens and pest insects. Current limitations on these populations by cold winter temperatures are expected to gradually release. For instance, the first infestations of new pathogens (e.g., Phytophthora inflata) and insect species, e.g., sawflies (Acantholyda spp.), has been recorded in Finland. Decreases in soil frost might lead to higher wind and snow damages, increasing consequential damage by bark beetles. A lack of soil frost is also expected to cause problems for tree harvesting, which necessarily should be concentrated more towards the summer months implying higher risks for root damage. Earlier bud burst and delayed growth cessation are likely to increase the risk of frost damage in early spring and autumn. Summer droughts are assumed to negatively affect forests in the southern part of the Boreal region.

Atlantic zone Experts expect that in the Atlantic zone forest productivity will increase in mountainous areas and at sites with sufficient water availability, whereas it is likely to decrease in areas prone to drought stress, e.g., in the eastern part of Ireland and the UK, in NE- and SW Germany and in S-SE of France. Increases in productivity have already been observed at higher altitudes, close to the tree line, but also in other areas. In the UK, for example, there has been an increase in productivity of $2 \mathrm{~m}^{3} \mathrm{ha}^{-1}$ year $^{-1}$ at sites with good soil moisture conditions (cf. Broadmeadow et al. 2005). On the other hand, decreases in productivity have been observed at dry areas as, considering France as example, in the Southern Alps for Scots pine and in the southern Massif Central for Norway spruce. Phenological 
observations indicated growth prolongation of 8-12 days for major tree species over the last 50 years, although regionally bud burst advanced considerably more. On the other hand, tree growth and vitality in the Atlantic region are expected to be at high risk of enhanced biotic disturbances and extreme climatic events. Pest insects, like gypsy moth (Lymantria dispar) and oak processionary (Thaumetopoea processionea), became more abundant, and formerly harmless pathogens suddenly got virulent (e.g., Chalara fraxinea on European ash and Sphaeropsis sapinea on Pinus spp.). With increasing temperatures, massive outbreaks of, e.g., spruce bark beetle (Ips typographus) and large pine weevil (Hylobius abietis) might also occur. Devastating storms caused major damage to forests in the Atlantic region in the last two decades. For instance, storms as Lothar (1999), Kyrill (2007), and Emma (2008) caused substantial losses of standing wood in Germany and Czech Republic, locally also enhanced by the historically high stocks. Less information on winter floods were reported in the questionnaire, but negative impacts have been observed locally, e.g., a decline of pedunculate oak (Quercus robur L.) in central France due to temporary water-logged sites and saturated soils in spring. Negative effects of storms (wind throw) and winter floods (oxygen shortage) are predicted to increase in the future. Decreases in vitality due to drought have been frequently reported for the extremely dry year 2003 and subsequent years, for instance in southern France (for Scots pine, silver fir, and Norway spruce), southern Belgium (Norway spruce and European beech), and eastern Czech Republic (Norway spruce). With increasingly dry summers, some areas (e.g., shallow freely draining soils in south and east England) will become unsuitable for many local tree species, whereas in other regions suitability might increase (e.g., north England and Scotland). As for other species, Norway spruce is expected to retreat from its actual range towards higher altitudes and colder regions.

Continental zone As for the Atlantic zone, forest productivity in the Continental zone is expected to increase with rising temperature and $\mathrm{CO}_{2}$ concentrations, only at sites with sufficient water availability. The questionnaire revealed that up to date, the positive effects of climate change generally outweighed the negative impact of water limitation. In fact, at the national level of the Continental zone, many countries reported slight increases in productivity (e.g., Austria, Hungary, Poland, Slovenia), whereas a general decrease in productivity was mentioned by Slovakia only. However, this trend is likely to change in the future. Decline in tree vitality are expected to be mostly associated with drought, directly, indirectly (abiotic attacks following drought), or in combination to high temperature. Thus, growth decline will be more pronounced at low-altitude and dry sites compared to high-altitude (or latitude, as in
Estonia) and wet sites. For instance, decreases in vitality for all commercially relevant tree species were observed in the eastern lowland of Austria, whereas pedunculate oak declined remarkably due to lowered groundwater table in Slovenia in the last decades. In some regions, negative effects have been observed only in case of extreme drought events, e.g., in low-altitude coniferous plantations in Bulgaria. The magnitude of the windstorm damage varied among countries but was overall relevant. In Romania, $28 \%$ of forests are vulnerable to wind throw, whereas more than $90 \%$ of the forests are damaged by wind in Slovakia. All Austrian forests showed increase in wind damage, with water-logged sites being particularly vulnerable. Wind throw is expected to increase in the whole Continental zone, and wind damaged stands are susceptible to bark beetle attacks (e.g., spruce bark beetle and common pine shoot beetle (Tomicus piniperda)). New biotic pests and increased virulence of current pests have been reported for most Continental countries. In particular, Mediterranean insects are expected to migrate into the Continental zone (e.g., for Serbia). High soil temperatures are favorable for fungi (e.g., Heterobasidion annosum). Increased fire risk was reported only by a minority of the countries. Overall, considering all disturbances (drought, wind, pests, etc.), the most affected tree species are Norway spruce (growing outside its natural range) and beech. As for the Boreal and Atlantic zone, upward shifts of northern tree species are observed and expected to continue in the future, as well as colonization of thermophilic species.

Mediterranean region In the Mediterranean region, particularly large productivity losses are expected, as water will become increasingly limited with projected increases in frequency and severity of summer droughts. For example, a reduction in site index is expected in maritime pine (Pinus pinaster Ait.) in southern Spain, and in Portugal, a decrease in the annual growth of cork oak (Quercus subur L.) and consequently in the cork production is foreseen. The extension of the growing season (e.g., growth duration of deciduous plants has increased by 3-6 weeks since 1950 in Spain (Peñuelas et al. 2002), bud burst advanced by about 15 days since 1960 in Italy) will likely not compensate for the negative impact of drought on forest productivity. Although no information on observed impacts on forest productivity is available at the national level for Mediterranean countries, a general loss in tree vitality was recorded. In the last 20 years, the more frequent drought episodes have caused a loss of $75 \%$ of forest species foliage in Italy, particularly of beech and oak in the Apennines. Decay and dieback of Mediterranean tree species like holm oak (Quercus ilex L.), cork oak, and stone pine (Pinus pinea L.), as well as of mountainous coniferous species like silver fir (Abies alba Mill.) and Scots pine are observed in Spain where, however, lack 
of management and stand aging have been considered additional vulnerability factors. On the other hand, in Cyprus, even drought adapted, typical Mediterranean species (e.g., Quercus alnifolia, Cistus spp.) died on poor sites, at all altitudes and in stand types differing in age and mixtures.
For the future, increased mortality is expected. Furthermore, climatic changes and extreme climatic events are predicted to increase the occurrence and virulence of abiotic pests. For instance, a rise in the number of beetle outbreaks (e.g., Orthotomicus erosus Wollaston) has been observed in

Table 1 Overview of hot spots identified for nine countries in Europe

\begin{tabular}{|c|c|c|c|}
\hline Country & Hot spot & Impact factor & Description \\
\hline UK & West Scotland: Sitka spruce & Wind & $\begin{array}{l}\text { Wind throw of spruce stands that are unstable due to shallow root } \\
\text { systems and root mortality occurring under persisting anaerobic } \\
\text { conditions in winter, especially on west-facing slopes }\end{array}$ \\
\hline UK & East Scotland: Sitka spruce & Drought & $\begin{array}{l}\text { Drought cracking of shallow-rooted stands, especially on south-facing } \\
\text { slopes }\end{array}$ \\
\hline UK & $\begin{array}{l}\text { East England: Corsican pine and } \\
\text { other pine spp. }\end{array}$ & Pathogen & $\begin{array}{l}\text { The fungus Dothistroma septosporum causes needle blight, } \\
\text { especially in pure, even-aged plantations }\end{array}$ \\
\hline UK & $\begin{array}{l}\text { Southeast England: European } \\
\text { beech }\end{array}$ & Drought & $\begin{array}{l}\text { Fluctuating water tables due to wet winters and drier summers cause } \\
\text { beech mortality }\end{array}$ \\
\hline UK & Southwest England: Japanese larch & Pathogen & $\begin{array}{l}\text { The plant pathogen Phytopthora ramorum infected larch starting in } \\
2009 \text { and causes mortality. Mild and wet winters improve } \\
\text { conditions for P. ramorum }\end{array}$ \\
\hline Germany & $\begin{array}{l}\text { Berlin-Brandenburg and Upper- } \\
\text { Rhine Valley: various species }\end{array}$ & Drought & $\begin{array}{l}\text { The vulnerability of forest sites that are already today characterized } \\
\text { by high temperatures and low precipitation amounts will increase }\end{array}$ \\
\hline Switzerland & $\begin{array}{l}\text { Inner-Alpine dry valleys (Valais): } \\
\text { Scots pine }\end{array}$ & Drought & $\begin{array}{l}\text { Scots pine is replaced by natural regeneration of sessile oak and } \\
\text { silver birch }\end{array}$ \\
\hline Czech Republic & $\begin{array}{l}\text { Sumava Mountains: Norway } \\
\text { spruce }\end{array}$ & Pest insects & Large bark beetle outbreaks damaged Norway spruce forests \\
\hline Czech Republic & Moravia-Silesian: Norway spruce & Drought & Dieback of spruce after drought in 2003 \\
\hline Croatia & Lowlands: sessile oak & Drought & $\begin{array}{l}\text { Vulnerability depends on additional wetting by floods and } \\
\text { groundwater }\end{array}$ \\
\hline Romania & Steppe limit: Quercus spp. & $\begin{array}{l}\text { Drought; pest } \\
\text { insects }\end{array}$ & $\begin{array}{l}\text { Tree vitality and growth is negatively affected in drier regions, and } \\
\text { are associated with attacks of the gypshy moth }\end{array}$ \\
\hline Romania & Mountain areas: Norway spruce & Pest insects & $\begin{array}{l}\text { Infestations of bark beetles and pine weevils are increasingly } \\
\text { observed at higher elevations }\end{array}$ \\
\hline Romania & $\begin{array}{l}\text { Wind exposed sites: Norway } \\
\text { spruce }\end{array}$ & Wind & $\begin{array}{l}\text { An increase in wind throw damage is observed in shallow-rooted } \\
\text { stands }\end{array}$ \\
\hline Slovenia & Nationwide: European ash & Pathogen & Infestations by Chalara fraxinea \\
\hline Slovenia & Nationwide: sessile oak & Drought & A decrease in vitality and diameter increment is observed \\
\hline Slovenia & Lowlands: Norway spruce & $\begin{array}{l}\text { Drought; pest } \\
\text { insects; wind }\end{array}$ & $\begin{array}{l}\text { Damage and growth decline of spruce, especially at low-altitude } \\
\text { sites that are outside the native range of the species }\end{array}$ \\
\hline Slovenia & Dinaric fir-beech forests & Drought & $\begin{array}{l}\text { Growth decline of fir at sites with high mean temperatures on } \\
\text { carbonate bedrock }\end{array}$ \\
\hline Spain & $\begin{array}{l}\text { Lower limits of Northern Iberian } \\
\text { range: Scots pine }\end{array}$ & Drought & Scots pine is substituted by maritime pine \\
\hline Spain & Southeast Spain: Aleppo pine & Drought & $\begin{array}{l}\text { Semiarid even-aged forests and plantations of Aleppo pine on } \\
\text { limestone rocky soils in an area with }<250 \mathrm{~mm} \text { rainfall suffer from } \\
\text { drought }\end{array}$ \\
\hline Spain & Southeast Spain: maritime pine & Drought & A decrease in site productivity is expected \\
\hline Greece & Taygetos mountains: Greek fir & $\begin{array}{l}\text { Drought; pest } \\
\text { insects }\end{array}$ & Bark beetle infestations, especially on poor and dry sites \\
\hline Greece & Parnitha Mountain: Greek fir & Drought & $\begin{array}{l}\text { Dieback of fir on very poor soil on calcareous bedrocks, especially } \\
\text { on steep south-southwest-exposed slopes }\end{array}$ \\
\hline Greece & Pieria Mountain: Scots pine & Drought; pathogen & $\begin{array}{l}\text { Dieback of pine due to infestation by the fungus Peridermium pini } \\
\text { and insect damage, especially in dry years }\end{array}$ \\
\hline Greece & $\begin{array}{l}\text { Kalampaka forest: sweet chestnut, } \\
\text { pedunculate oak, and Turkey oak }\end{array}$ & Drought & $\begin{array}{l}\text { Reductions in rainfall trigger distributional shifts and cause the } \\
\text { invasion of Bulgarian fir and black pine in formerly mixed forests } \\
\text { of broadleaved deciduous trees }\end{array}$ \\
\hline
\end{tabular}


Cyprus. Further, the abundance of defoliating insect species such as the caterpillar of the pine processionary moth (Thaumetopoea wilkinsoni) is expected to increase. In Portugal, infestations by beetles (also vectors of nematodes, as Monochamus galloprovinciallis), fungi associated with host stress (e.g., Phytophtora cinnamon), and multivoltine species (e.g., Ips sexdentatus) are all expected to become more severe. Further, global warming will intensify the frequency of large-scale forest fires (>500 ha) and the progress of desertification, particularly in southern Italy and Cyprus. Drought and heat waves will also affect natural regeneration and mortality of seedlings. Hampered regeneration and adverse climate will promote a drastic reduction of the actual distribution of tree species like cork oak and Scots pine in Spain, where altitudinal migration have already been observed (e.g., Q. ilex occupying former Fagus sylvatica areas in NE Spain). In Italy, the distribution of beech, sweet chestnut (Castanea sativa Mill.), and sycamore maple (Acer pseudoplatanus L.) will decrease, whereas Turkey oak (Quercus cerris L.) and Ulmus spp. might become more abundant. The risk of local disappearance for (endemic) species growing already at the highest altitudes (thus not having the possibility to migrate) has been detected in Cyprus, Greece, and Spain.

\subsection{Hot spots of climate change for European forests}

From the countries that responded to the questionnaire, nine countries provided maps and descriptions of so-called hot spots of climate change impacts (Table 1). A visualization of hot spots on the European Forest Map was hampered as the spatial scales at which individual countries defined hot spots differed greatly and ranged from regions (e.g., Upper-Rhine Valley, Germany) to local forest sites (Parnitha forest, Greece). Generally, the identified hot spots are in line with described impacts of climate change on forest ecosystems (Section 3.2), and hence offer illustrative case studies, which show how future changes in climate may affect large(r) forest areas in specific bioclimatic regions.

The variable answers of the few countries that responded on hot spots highlights that a common understanding on the concept is still lacking. Nevertheless, the identification of hot spots could be very helpful, as it would enable forest managers to concentrate the activities of adaptation to the regions where significant investments are necessary to establish more resilient forests (so-called active adaptation, according to Millar et al. 2007). But this requires a commonly accepted method to quantify vulnerability, which would help to delimit these areas of higher vulnerability according to predefined thresholds. Among the most promising methods are indices (e.g., Blatt et al. 2010; Davison et al. 2012), the modeling of range distribution of tree species (so-called species distribution models, e.g., Heikkinen et al. 2006; Marmion et al. 2009) or physiological models (e.g., Coops et al. 2011).

\subsection{Adaptive forest management needs}

A significant part of the countries that responded (32\%) stated that to date no adaptation measures to climate change have been conducted (Fig. 1, left). Some of these countries just pointed out that forest management had to focus more on an adequate species-site matching and had to be sustainable, measures which per se are not adaptation measures to climate change. Nevertheless, among the truly adaptation measures mentioned, forest conversion measures were ranked first. In several Central European countries with a gap between the current and the former tree species distribution, programs of forest conversion from pure homogeneous to mixed and heterogeneous forests are under way. Anyhow, the driver for these forest conversion programs was (and is) only partly climate change, but mainly the concern of lacking stability of the large still pure and even-aged high forest stands against periodically occurring storms and pests such as bark beetle attacks. Increase of tree species diversity and change of forest structure into unevenaged are the second and third mentioned measures here, irrespective of bioclimatic region (Fig. 1, left). With regard to the management measures to be taken to adapt our forests in the future, at first the increase of tree species richness was emphasized, then tending and forest structure change, inclusion of risk management, and finally soil management (Fig. 1, right).

Concerning the "tree species question" as the most important adjustment screw for forest adaptation, there is no significant difference between the four bioclimatic regions. Of course, the single tree species which are recommended in the different regions differ.

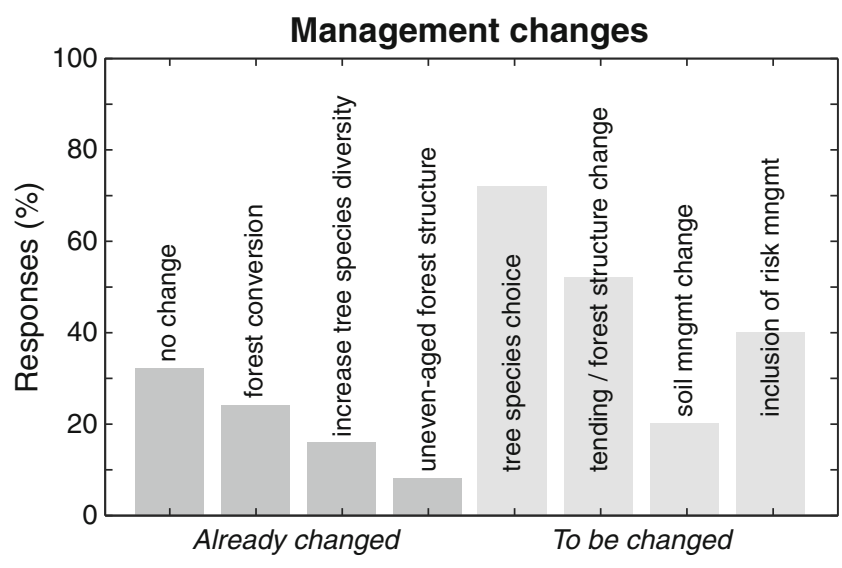

Fig. 1 Bar graph of adaptation measures already undertaken (dark gray bars) and measures which should be taken in the future (light gray bars) $(n=24)$ 
The strong emphasis on species (provenance) choice and an increase in species richness is in line with several recent publications, which underline the significance of species diversity for the adaptive capacity of forests (e.g., Bolte et al. 2009; Brang et al. 2008). Second, the silvicultural system and the right tending of stands are of high relevance in order to reduce risks or vulnerabilities. In a synthesis article, Bolte et al. (2010) cite several studies that support the hypothesis that thinning in general increases the individual resistance of trees against drought, with still some questions remaining unsolved. Ibisch et al. (2010) highly recommend continuouscover forest systems to constantly maintain a high level of biomass and an equilibrated forest microclimate. The latter can be seen as a proxy for higher resilience of forest ecosystems against drought stress. Furthermore, the inclusion of risk management elements is a prominent measure of forest adaptation (Hanewinkel 2008). Among these, risk identification, handling of risks (e.g., avoiding of risky actions), and risk control are recommended steps. The adaptation measures that have been proposed by the experts are in good agreement with an extensive collection of adaptation measures compiled by working group II of the COST Action FP0703 ECHOES. This collection is set up as an online toolbox and contains more than 480 context-specific adaptation measures (i.e., with regard to country, region, and tree species). A high number of the adaptation recommendations mentioned by the European experts match with the adaptation measures compiled in a review by Kolström et al. (2011).

\section{Lessons learnt and conclusions}

Several studies have investigated the effects of climate change or extreme events on forests in Europe following various approaches, for example, dendrochronology (e.g., Jump et al. 2006; Pichler and Oberhuber 2007), species distribution modeling (Maiorano et al. 2012), remote sensing (Jolly et al. 2005), ecosystem carbon dioxide fluxes (Ciais et al. 2005), or literature reviews (Lindner et al. 2010). Our analysis is different as it is based on the personal opinion of local experts. This approach does not provide a consolidate assessment of the situation (e.g., lack of validation, no random selection of the experts). However, our analysis has the value to report the views and feeling that experts around Europe actually perceive in their practice and to provide first indications on climate change impacts on less-described European forests (e.g., in the east and the south). Overall, experts in the Atlantic, Continental, and, particularly, Mediterranean zones are concerned about summer drought for both its direct (e.g., water limitation) and indirect negative effects (promotion of pests, everywhere, and fires, in the southern zones). Experts of the Atlantic and Continental regions are also concerned about the direct impacts of warming on biotic disturbances (e.g., pests) and about extreme events (e.g., wind storms). The level of concern of experts in the Boreal zone is more limited as no major negative impacts were observed and climate change might be beneficial for northern forests.

It has to be emphasized that both impacts and adaptation measures vary considerably in the European regions, which makes it difficult to establish a conclusive approach throughout Europe. The questionnaire has provided information on important adaptation measures that are already being applied and has further identified areas where future adaptation needs have to be concentrated, while at the same time showing the diversity in forest adaptation needs in Europe. It will therefore be of utmost importance to implement regionally based adaptation measures which are accepted by the stakeholders involved.

Acknowledgments The authors are grateful to all country nationals that contributed to this study by filling out the questionnaire. In particular, they wish to thank: Andrej Boncina, Asunción Cámara Obregón, Atilla Eredics, Boris Vrbek, Brian Tobin, Bruno Lasserre, Carlos García Güemes, Caroline Vincke, Daphné Asse, Duncan Ray, Elena Rafailova, Elina Vapaavuori, Emil Cienciala, Even Bergseng, František Zemek, Gabriel Spyroglou, Giorgio Matteucci, Guy Landmann, Harald Kvaalen, Heli Peltola, Henn Korjus, Hilppa Gregow, Igor Stefancik, Jan Weger, Joana Amaral Paulo, Kaliopi Radoglou, Kevin Black, Kirsti Jylhä, Liubcho Trichkov, LouisMichel Nageleisen, Lucian Dincă, Mait Lang, Manuela Branco, Marco Marchetti, Martine Rebetez, Mathieu Jonard, Matija Klopcic, Matthew Saunders, Matteo Vizzarri, Michael Englisch, Michael Müller, Miroslav Svoboda, Myriam Legay, Nikica Ogris, Paula Soares, Quentin Ponette, Rafael Calama Sainz, Roque Rodríguez Soalleiro, Savvas Andrea, Seppo Kellomäki, Seppo Neuvonen, Tibor Priwitzer, Tina Simoncic, Urs Mühlethaler, Veiko Uri, Victor Dan Păcurar, Vladimir Caboun, and Zoran Galić. This research was initiated within the COST Action FP0703 ECHOES' working group I on climate change impacts.

\section{References}

Blatt J, Ellner B, Strixner L, Kreft S, Luthardt V, Ibisch P (2010) Indexbasierte Erfassung der Klimawandel-Vulnerabilität von Wald- und Forstökosystemen im Nationalpark Unteres Odertal. In: Korn H, Schliep R, Stadler J (eds): Biodiversität und Klima - Vernetzung der Akteure in Deutschland VII. Ergebnisse des 7. Workshops an der Internationalen Naturschutzakademie des Bundesamtes für Naturschutz, Insel Vilm. 29.08.-01.09.2010. BfN Skripten 282: $55-59$

Bergh J, Freeman M, Sigurdsson B, Kellomäki S, Laitinen K, Niinisto S, Peltola H, Linder S (2003) Modelling the short-term effects of climate change on the productivity of selected tree species in Nordic countries. For Ecol Manage 183:327-340

Bolte A, Ammer C, Löf M, Madsen P, Nabuurs GJ, Schall P, Spathelf P, Rock J (2009) Adaptive forest management in central Europe: climate change impacts, strategies and integrative concept. Scan J For Res 24:473-482

Bolte A, Ammer C, Löf M, Nabuurs GJ, Schall P, Spathelf P (2010) Adaptive forest management: a prerequisite for sustainable forestry in the face of climate change. In: Spathelf P (ed) Sustainable 
forest management in a changing world - a European perspective. Managing Forest Ecosystems, vol 19. Springer, Heidelberg, pp 115-139

Brang P, Bugmann H, Bürgi A, Mühlethaler U, Rigling A, Schwitter R (2008) Klimawandel als waldbauliche Herausforderung. Schweiz Z Forstwes 159:362-373

Broadmeadow M, Ray D, Samuel CJA (2005) Climate change and the future for broadleaved tree species in Britain. Forestry 78:145-161

Christensen JH, Hewitson B, Busuoic A, Chen A, Gao X, Held R, Jones R, Kolli RK, Kwon W-T, Laprise R, Magana Rueda V, Mearns L, Menéndez CG, Räisänen J, Rinke A, Sarr A, Whetton P (2007) Regional climate projections. In: Solomon S, Qin D, Manning $\mathrm{M}$ et al (eds) Climate Change 2007: the physical science basis. Contribution of Working Group I to the fourth assessment report of the Intergovernmental Panel on Climate Change. Cambridge University Press, Cambridge

Ciais P, Reichstein M, Viovy N, Granier A, Ogée J, Allard V, Aubinet M, Buchmann N, Bernhofer C, Carrara A, Chevallier F, De Noblet N, Friend A D, Friedlingstein P, Grünwald T, Heinesch B, Keronen P, Knohl A, Krinner G, Loustau D (2005) Europewide reduction in primary productivity caused by the heat and drought in 2003. Nature 437:529-533

Coops NC, Waring RH, Beier C, Roy-Jauvin R, Wang T (2011) Modeling the occurrence of 15 coniferous tree species throughout the Pacific Northwest of North America using a hybrid approach of a generic process-based growth model and decision tree analysis. Appl Veg Sci 14:402-414

Davison J, Coe S, Finch D, Rowland E, Friggens M, Graumlich L (2012) Bringing indices of species vulnerability to climate change into geographic space: an assessment across the Coronado National Forest. Biodivers Conserv 21:189-204

Hanewinkel M (2008) Risiko und Klimawandel. FVA-Einblick + (Wald und Klima) 12, 1:16-19

Heikkinen RK, Luoto M, Araújo MB, Virkkala R, Thuiller W, Sykes MT (2006) Methods and uncertainties in bioclimatic envelope modelling under climate change. Prog Phys Geogr 30:751-777

Ibisch PL, Vega AE, Herrman TM (2010) (eds.) Interdependance of biodiversity and development under global change. Technical Series No. 54. Secretariat of the Convention on Biological Diversity, Montreal (second corrected edition)

Jolly WM, Dobbertin M, Zimmermann NE, Reichstein M (2005) Divergent vegetation growth responses to the 2003 heat wave in the Swiss Alps. Geophys Res Lett 32:1-4

Jump AS, Hunt JM, Peñuelas J (2006) Rapid climate change-related growth decline at the southern range edge of Fagus sylvatica. Glob Change Biol 12:2163-2174

Kolström M, Lindner M, Vilén T, Maroschek M, Seidl R, Lexer MJ, Netherer S, Kremer A, Delzon S, Barbati A, Marchetti M, Corona P (2011) Reviewing the science and implementation of climate change adaptation measures in European forestry. Forests 2:961982
Lindner M, Maroschek M, Netherer S, Kremer A, Barbati A, GarciaGonzalo J, Seidl R, Delzon S, Corona P, Kolström M, Lexer MJ, Marchetti M (2010) Climate change impacts, adaptive capacity, and vulnerability of European forest ecosystems. For Ecol Manage 259:698-709

Linkosalo T, Häkkinen R, Terhivuo J, Tuomenvirta H, Hari P (2009) The time series of flowering and leaf bud burst of boreal trees (1846-2005) support the direct temperature observations of climatic warming. Agric For Meteorol 149:453-461

Maiorano L, Cheddadi R, Zimmermann NE, Pellissier L, Petitpierre B, Pottier J, Laborde H, Hurdu BI, Pearman PB, Psomas A, Singarayer JS, Broennimann O, Vittoz P, Dubuis A, Edwards ME, Binney HA, Guisan A (2012) Building the niche trough time: using 13,000 years data to predict the effects of climate change on three tree species in Europe. Global Ecol Biogeogr. doi:10.1111/j.1466-8238.2012.00767.x

Marmion M, Parviainen M, Luoto M, Heikkinen RK, Thuiller W (2009) Evaluation of consensus methods in predictive species distribution modelling. Divers Distrib 15:59-69

Millar CI, Stephenson NL, Stephens SL (2007) Climate change and forests of the future: managing in the face of uncertainty. Ecol Appl 17:2145-2151

Nabuurs G-J, Pussinen A, Karjalainen T, Erhard M, Kramer K (2002) Stemwood volume increment changes in European forests due to climate change - a simulation study with the EFISCEN model. Glob Change Biol 8:304-316

Päivinen R, Lehikoinen M, Schuck A, Häme T, Väätäinen S, Kennedy P, Folving S (2001) Combining earth observation data and forest statistics. European Forest Institute Research Report 14. European Forest Institute and Joint Research Centre-European Commission

Peñuelas J, Filella I, Comas P (2002) Changed plant and animal life cycles from 1952 to 2000 in the Mediterranean region. Glob Change Biol 8:531-544

Pichler P, Oberhuber W (2007) Radial growth response of coniferous forest trees in an inner Alpine environment to heat-wave in 2003. For Ecol Manage 242:688-699

Reyer CR, Leuzinger S, Rammig A, Wolf A, Bartholomeus RP, Bonfante A, de Lorenzi F, Dury M, Gloning P, Jaoudé RA, Klein T, Kuster TM, Martins M, Niedrist G, Riccardi M, Wohlfahrt G, de Angelis P, de Dato G, François L, Menzel A, Pereira M (2013) A plant's perspective of extremes: terrestrial plant responses to changing climatic variability. Glob Chang Biol 19:75-89

Thies M, Hein S, Spiecker H (2009) Results of a questionnaire on management of valuable broadleaved forests in Europe. In: Spiecker H, Hein S, Makkonen-Spiecker K, Thies M (eds) Valuable broadleaved forests in Europe. European Forest Institute Research Report, vol 22. Brill, Leiden, pp. 27-41

Zheng D, Freeman M, Bergh J, Røsberg I, Nilsen P (2002) Production of Picea abies in south-east Norway in response to climate change: a case study using process-based model simulation with field validation. Scand J For Res 17:35-46 